\title{
Spatial gradients in trace metal concentrations in the surface microlayer of the Mediterranean Sea
}

\author{
Antonio Tovar-Sánchez ${ }^{1,2 *}$, Jesús M. Arrieta ${ }^{2}$, Carlos M. Duarte ${ }^{2,3}$ and Sergio A. Sañudo-Wilhelmy ${ }^{4}$ \\ ${ }^{1}$ Department Ecology and Coastal Management, ICMAN-Instituto de Ciencias Marinas de Andalucía (Consejo Superior de Investigaciones Científicas), Campus \\ Universitario Río San Pedro, Puerto Real, Cádiz, Spain \\ 2 Department of Global Change Research, Mediterranean Institute for Advanced Studies IMEDEA, Universidad de las Islas Baleares-Consejo Superior de \\ Investigaciones Científicas, Miguel Marqués 21, Esporles, Spain \\ ${ }^{3}$ The UWA Oceans Institute and School of Plant Biology, University of Western Australia, Crawley, WA, Australia \\ ${ }^{4}$ Department of Biological Sciences and Earth Sciences, University of Southern California, Los Angeles, CA, USA
}

\section{Edited by:}

Claire Mahaffey, University of

Liverpool, UK

Reviewed by:

Antonio Cobelo-Garcia, Instituto de Investigaciones Marinas - Consejo

Superior de Investigaciones

Cientificas, Spain

Marta Plavsic, Rudjer Boskovic

Institute, Croatia

${ }^{*}$ Correspondence:

Antonio Tovar-Sánchez, Campus

Universitario Río San Pedro, 11510

Puerto Real, Cádiz, Spain

e-mail:a.tovar@csic.es
The relationship between dust deposition and surface water metal concentrations is poorly understood. Dissolution, solubility, and partitioning reactions of trace metals from dust particles are governed by complex chemical, biological, and physical processes occurring in the surface ocean. Despite that, the role of the sea surface microlayer (SML), a thin, but fundamental component modulating the air-sea exchange of materials has not been properly evaluated. Our study revealed that the SML of the Mediterranean Sea is enriched with bioactive trace metals (i.e., $\mathrm{Cd}, \mathrm{Co}, \mathrm{Cu}$, and Fe), ranging from 8 (for $\mathrm{Cd}$ ) to 1000 (for $\mathrm{Fe}$ ) times higher than the dissolved metal pool in the underlying water column. The highest enrichments were spatially correlated with the atmospheric deposition of mineral particles. Our mass balance results suggest that the SML in the Mediterranean Sea contains about 2 tons of Fe. However, we did not detect any trends between the concentrations of metals in $\mathrm{SML}$ with the subsurface water concentrations and biomass distributions. These findings suggest that future studies are needed to quantify the rate of metal exchange between the SML and the bioavailable pool and that the SML should be considered to better understand the effect of atmospheric inputs on the biogeochemistry of trace metals in the ocean.

Keywords: sea surface microlayer, SML, trace metals, aerosol deposition, dust event, Mediterranean Sea

\section{INTRODUCTION}

The sea-surface microlayer (SML) has been defined as the top $1-1000 \mu \mathrm{m}$ of the surface ocean and it serves as the boundary layer between the atmosphere and the ocean. The SML is known to concentrate natural and anthropogenic materials from the atmosphere as well as to be a micro-habitat for a diverse range of organisms (i.e., bacteria, phytoplankton, zooplankton, and icthyo-neuston) (Cincinelli et al., 2001). This environmental compartment plays an important role in the exchange rate of gases and energy on a global scale (Agogué et al., 2004; Wurl and Obbard, 2004; Wurl et al., 2006, 2011; Wurl and Holmes, 2008). It has been reported that metals are enriched in the SML mainly from atmospheric deposition and from rising bubbles, and can be influenced by organic matter concentrations, $\mathrm{pH}$, and salinity, among other factors (Liss and Duce, 1997; Wurl and Obbard, 2004). While water-column trace metal concentrations, distributions and bioavailability in open ocean waters have been reported (e.g., Millero, 2006; Aparicio-González et al., 2012) SML studies are very limited and almost nonexistent for open ocean environments (Wurl and Obbard, 2004).

The Mediterranean Sea is a semi-enclosed basin with one of the highest rates of aeolian deposition in the world with strong pulses of mineral dust from Africa, in addition to consistent anthropogenic aerosol inputs from Europe (Bonnet and Guieu, 2006; Ternon et al., 2009; Jordi et al., 2012). The study of the interface between the ocean and atmosphere is therefore important to better understand trace metal distributions, as well as the processes influencing vertical fluxes of materials, phytoplankton uptake, and particulate scavenging occurring in surface waters of the Mediterranean Sea.

In this study, we established trace metal distributions in the SML and in the sub-surface water $(<1 \mathrm{~m})$ as well as the aerosol composition along a longitudinal transect from the western to the eastern parts of the Mediterranean Sea. The different Mediterranean marine regions were sampled twice within a single month both under high and low atmospheric deposition conditions. A network analysis was used to determine if any relationship exists between the various metal concentrations measured (SML, total and dissolved pools, and dust particles) and bacterial and/or phytoplankton biomass.

\section{METHODS}

Samples for this study were obtained on board the Spanish R/V BIO García del Cid during the cruise THRESHOLDS I, from June 4 to July 3, 2006. The concentrations of trace metals were measured in the SML, in the underlying water column, and in atmospheric particles collected in different regions of the Mediterranean Sea (i.e., Eastern and Western sections, Aegean, Marmara, and Black Seas). The cruise consisted of 2 transects sampling a total of 38 stations under different atmospheric 
deposition conditions (Transect 1- stations 1-17, June 4-16, 2006 under low atmospheric deposition; and transect 2, stations 1838; June 19 to July 3, 2006 under high atmospheric deposition) (Figure 1).

\section{WATER SAMPLING AND ANALYSIS}

SML and sub-surface water (SSW: collected to $\sim 1$ m depth) samples were collected under calm sea conditions (average wind speed in the cruise: $3.7 \pm 3.1 \mathrm{~m} \mathrm{~s}^{-1}$ ) from a pneumatic boat deployed $\sim 2 \mathrm{~km}$ away from the research vessel to avoid metal contamination. For SML sampling (unfiltered water), we used a glass plate sampler (Stortini et al., 2012), which was acid cleaned overnight and rinsed thoroughly with MQ-water. In order to quantify any procedural contamination, we collected field SML blanks by rinsing and collecting $0.5 \mathrm{~L}$ of ultra pure water. The surface microlayer thickness $\left(S M L_{T}\right.$ in $\left.\mu \mathrm{m}\right)$ was calculated according to the formula of Wurl (2009):

$$
S M L_{T}=V_{S} \cdot 10^{4} / N\left(A_{p} \cdot 2\right)
$$

where $\mathrm{V}_{\mathrm{S}}$ is the volume sampled $(\mathrm{mL}), \mathrm{N}$ the number of dips, and $A_{p}$ the surface area of the glass plate $\left(\mathrm{cm}^{2}\right)$. We used a $975 \mathrm{~cm}^{2}$ surface area glass plate and about 100 dips were required to collect $500 \mathrm{ml}$ of water at each station. With these parameters, we calculated a $S M L_{\mathrm{T}}$ of $26 \mu \mathrm{m}$. Total (unfiltered) surface water samples (TSSW) were collected using an acid-washed Teflon tubing connected to a peristaltic pump. Dissolved water samples (DSSW) were filtered in-situ through an acid-cleaned polypropylene cartridge filter $\left(0.22 \mu \mathrm{m}\right.$; MSI, Calyx $\left.{ }^{\circledR}\right)$ (Tovar-Sánchez, 2012). All water samples (TSSW, SML, and DSSW) were collected in $0.5 \mathrm{~L}$ acid cleaned low-density polyethylene plastic bottle and acidified on board to $\mathrm{pH}<2$ with ultrapure-grade $\mathrm{HCl}$ in a class-100 HEPA laminar flow hood. Metals ( $\mathrm{Cd}, \mathrm{Co}, \mathrm{Cu}, \mathrm{Fe}, \mathrm{Mo}$, and $\mathrm{V}$ ) were preconcentrated using an organic extraction method (Bruland et al., 1979), and quantified by ICP-MS (PerkinElmer ELAN DRC-e).
The limit of detection, calculated as three times the standard deviation of the blank values ranged from $1 \mathrm{pM}$ for Co to $0.6 \mathrm{nM}$ for V. The accuracy of the metal analyses was established using Seawater Reference Material for Trace Elements (NASS5, NRCCNRC) with recoveries ranging from $85 \%$ for $\mathrm{V}$ to $100 \%$ for $\mathrm{Cd}$.

Bacterial abundance was estimated by flow cytometry (Marie et al., 1997) and chlorophyll-a concentrations were determined fluorometrically (Parsons et al., 1984) using a Turner Design fluorometer after pigment extraction overnight with $90 \%$ acetone.

\section{AEROSOL SAMPLING AND ANALYSIS}

Coarse aerosol particles were collected on acid-washed cellulose filters (Whatman 41) using a high-volume particle collector (MCV: CAV-A/HF). The aerosol collector was mounted over the vessel bridge and connected to a wind direction sensor. In order to avoid contamination from the ship exhaust, the sampler automatically closed when wind direction deviated from the bow. Sampling flow rate was set at $40 \mathrm{~m}^{3} \mathrm{~h}^{-1}$ and the sampling volumes ranged from 100 to $800 \mathrm{~m}^{3}$ of filtered air. A microwave acid digestion procedure using $\mathrm{HNO}_{3}, \mathrm{HF}$, and $\mathrm{H}_{2} \mathrm{O}_{2}$ followed by ICP-AES (Perkin Elmer, Optima 5300 DV) quantification was used to measure total metal levels in the aerosol filters (Pekney and Davidson, 2005). The limit of detection for the particulate metal analyses ranged from $1.3 \mathrm{nM}$ for Cd to $124 \mathrm{nM}$ for Fe.

Bulk aerosol concentrations over the sampling area were calculated using the daily L3 level estimates from the MODerate Resolution Imag-ing Spectroradiometer (MODIS) satellite data (http://gdata1.sci.gsfc.nasa.gov/daac-bin/G3/gui.cgi?instance_id= MODIS_DAILY_L3).

\section{ASSOCIATION NETWORKS}

The association networks between the metal concentrations measured in the Mediterranean Sea (aerosols and water column) with other parameters were constructed by computing the Pearson

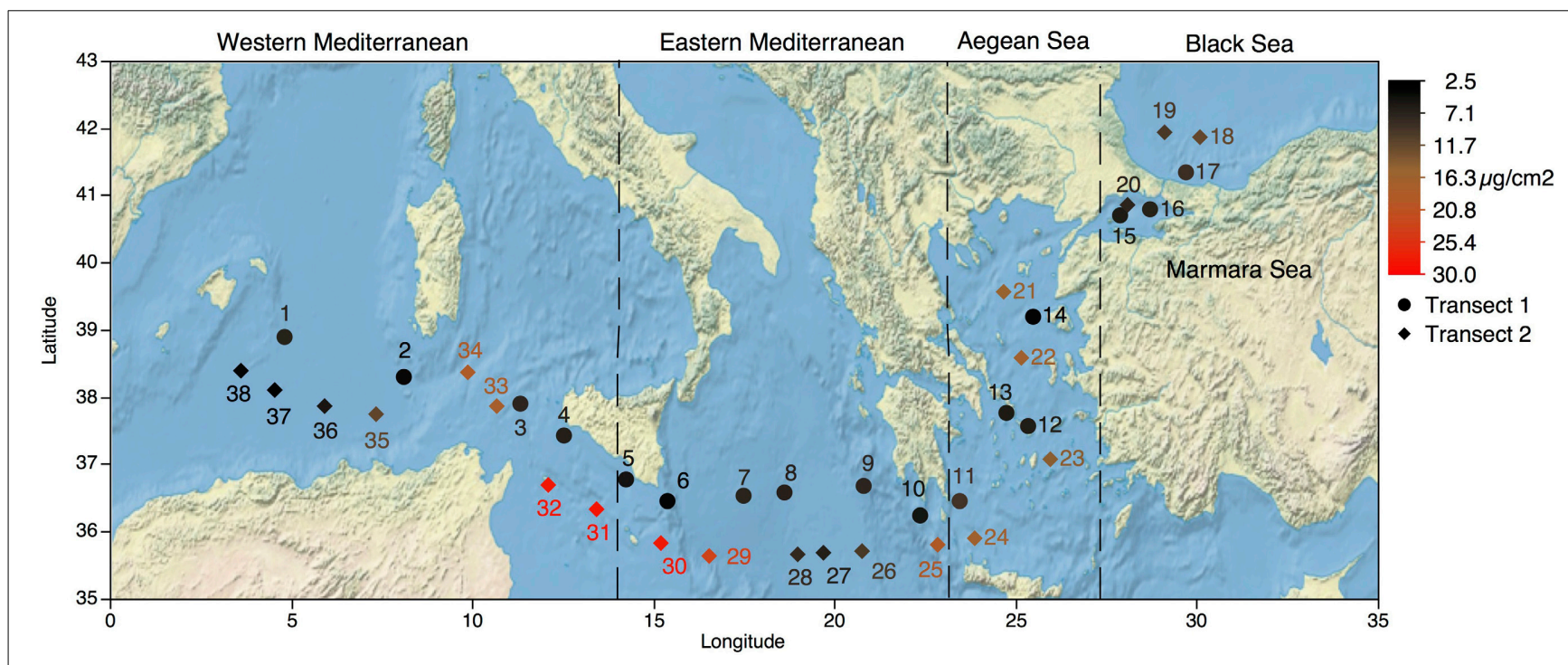

FIGURE 1 | Location of the sampling sites along the Mediterranean Sea. Color scale indicates bulk aerosol concentrations from satellite observations (MODIS). 
correlation coefficient between each set of variables. Only positive correlations were used in the analysis and the resulting networks were plotted with the Cytoscape software environment program (Shannon et al., 2003), using the Pearson product-moment correlation coefficients as weighting variables of the "edge-weighted spring embedded" layout.

\section{RESULTS AND DISCUSSION \\ SURFACE WATER CONCENTRATIONS AND LONGITUDINAL DISTRIBUTIONS OF TRACE METALS}

Metal concentrations varied broadly among the three water column reservoirs and exhibited a strong spatial variability within the Mediterranean basin (Table 1 and Figure 2). High concentrations of $\mathrm{Cd}, \mathrm{Co}, \mathrm{Cu}$, and $\mathrm{Fe}$ in the DSSW pool were measured in the Marmara and Black Seas (e.g., mean DSSW \pm SD averaged from both Seas; $91 \pm 19 \mathrm{pM}, 366 \pm 138 \mathrm{pM}, 7.6 \pm 1.1 \mathrm{nM}$ and $3.4 \pm 1.2 \mathrm{nM}$, respectively). In contrast, levels of Mo and $\mathrm{V}$ in the three pools (SML, TSSW, and DSSW) in the Marmara and Black Seas were about $50 \%$ lower (e.g., mean DSSW \pm SD; $50.6 \pm 9.1 \mathrm{nM}$ and $10.8 \pm 2.9 \mathrm{nM}$, respectively) than those measured in other regions of the Mediterranean Sea $(120.6 \pm 8.1 \mathrm{nM}$ and $25.7 \pm 2.6 \mathrm{nM}$, respectively). This is consistent with the geochemistry of the Marmara and Black Seas where high metal levels have been linked to anthropogenic inputs and river discharges (OGUZ, 2005; Okuş et al., 2007). In contrast, particle scavenging in the anoxic or near-anoxic waters of the Black Sea seems to be responsible for the low Mo and V concentrations (Emerson and Huested, 1991). This metal removal is consistent with the low oxygen saturation levels measured in the Black (average: $28 \pm$ $4 \%$ ) and Marmara Seas (average: $34 \pm 2 \%$ ), in contrast to the $74 \pm 2 \%$ calculated for the rest of the sampling locations along the Mediterranean. The increased nutrients and metals inputs to the Black Sea have induced a basin-scale eutrophication (Chu et al., 2005) which is reflected in the high chlorophyll-a concentration measured in those waters (i.e., $1.7 \pm 0.2 \mathrm{mg} \mathrm{m}^{-3}$ ). Although DSSW metal concentrations were less variable in the other regions of the Mediterranean Sea, higher levels $(p<0.005)$ of $\mathrm{Cd}(97 \pm$ $13 \mathrm{pM})$, Co $(169 \pm 61 \mathrm{pM})$, and $\mathrm{Cu}(2.7 \pm 0.9 \mathrm{nM})$ were measured in the Aegean Sea, in comparison to the concentrations detected in the Eastern (Cd: $79 \pm 6 \mathrm{pM}, \mathrm{Co}: 115 \pm 20 \mathrm{pM}$, and $\mathrm{Cu}$ : $1.6 \pm 0.2 \mathrm{nM})$ and Western (Cd: $70 \pm 9 \mathrm{pM}, \mathrm{Co}: 95 \pm 30 \mathrm{pM}$, and Cu: $1.6 \pm 0.3 \mathrm{nM})$ Mediterranean. Mean Fe, Mo, and V concentrations in the DSSW pool were similar $(p<0.005)$ in these three regions (i.e., Aegean Sea: $3.0 \pm 0.7 \mathrm{nM}, 117.0 \pm 9.9 \mathrm{nM}, 24.6 \pm$ 3.7; Eastern: $3.1 \pm 1.4 \mathrm{nM}, 123.0 \pm 4.3 \mathrm{nM}, 25.7 \pm 1.6 \mathrm{nM}$, and Western: $2.8 \pm 1.7,120.7 \pm 9.2 \mathrm{nM}, 26.3 \pm 2.4 \mathrm{nM})$. These concentrations are consistent with the levels previously reported for the Mediterranean Sea (Lewis and Landing, 1992; Vega and van den Berg, 1997; Yoon et al., 1999).

Metals with a strong affinity for organic ligands (i.e., Cd, Co, $\mathrm{Cu}, \mathrm{Fe}$ ) (Bruland and Lohan, 2006) were enriched in the SML, $8,41,16$, and 1000 times higher respectively, over the total metal fraction measured in the subsurface water (TSSW) and 12, 55, 20, and 4700 times over the dissolved fraction (DSSW) (Table $\mathbf{1}$ and Figures 2, 3). These metal enrichments are consistent with the high levels of organic matter and surfactants found in the SML (Buck et al., 2010; Wurl et al., 2011). Less reactive elements such

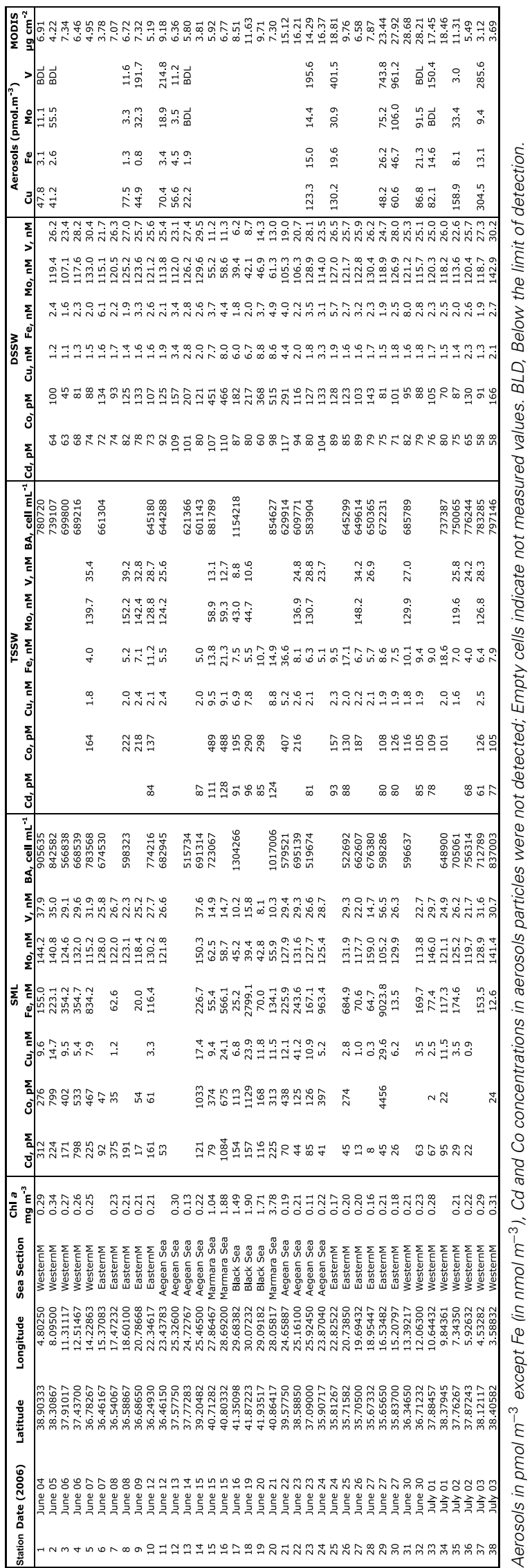




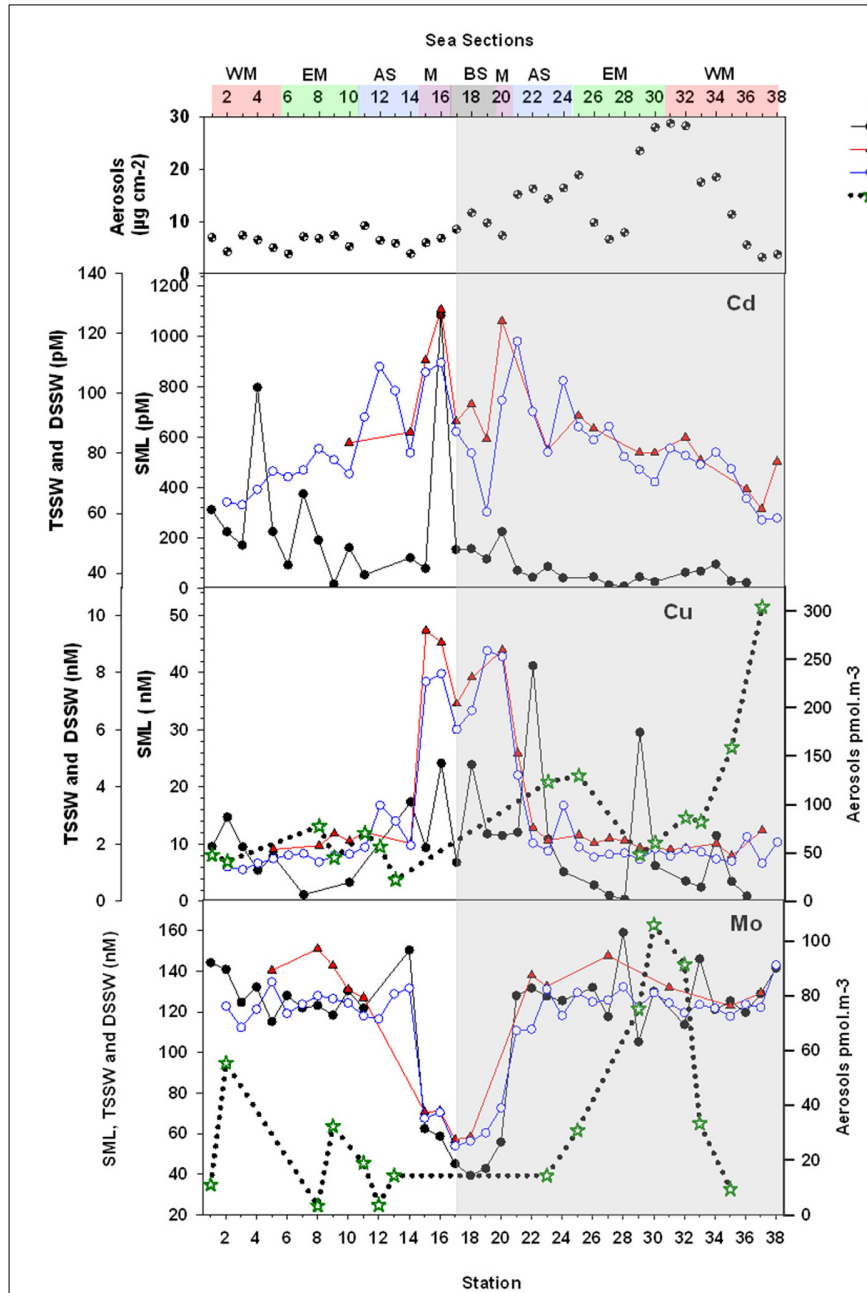

FIGURE 2 | Bulk aerosol and metal concentrations measured in the different water-column compartments. SML, surface micro-layer: black dots; TSSW, total subsurface water: red triangles; DSSW, dissolved subsurface water: open blue dots; and aerosols, black-white dots. Shaded

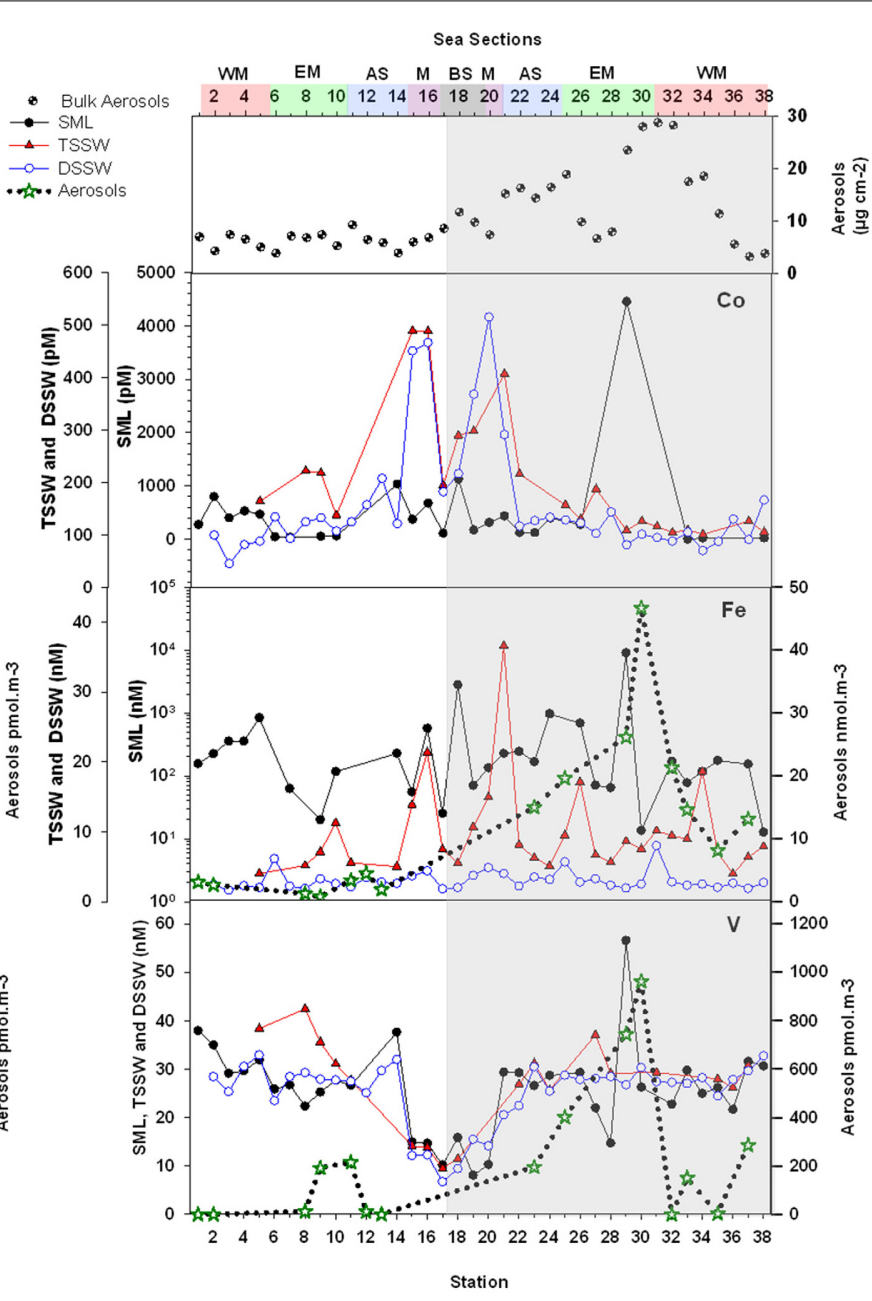

area represents the second transect. Shaded colors in the upper x-axis shows stations in different regions of the Mediterranean Sea: WM (Western Mediterranean), EM (Eastern Mediterranean), AS (Aegean Sea), M (Marmara Sea), and BS (Black Sea). as Mo and V showed comparable concentrations among the different water compartments. The metal composition of the SML has not been extensively studied and different sampling protocols which influence the thickness of the sampling micro-layer, make any comparison with results obtained in other studies difficult. Despite that limitation, the SML metal enrichments calculated for the Mediterranean Sea were in good agreement with values reported elsewhere (Wurl and Obbard, 2004).

\section{CONTRIBUTION OF AEROSOL INPUTS TO TRACE METAL CONCENTRATIONS AND DISTRIBUTIONS IN THE SEA SURFACE MICRO LAYER}

During our second transect, the Eastern and Western regions of the Mediterranean were influenced by an African aerosol dust deposition event (Figures 1, 2). However, aerosols backtrajectories (Figure 4) showed that the Mediterranean was also influenced by atmospheric particles originating from other different sources: the Aegean Sea (stations 21-24) and Western regions (stations 31-34) were receiving aerosols from European sources while the atmospheric particles deposited in the Eastern Mediterranean were from northern Africa (stations 29 and 30). Despite the back-trajectory results, the MODIS information showed that atmospheric particle densities higher than the background of $10 \mu \mathrm{g} \mathrm{cm}^{2}$ were only detected in the Aegean Sea and in the Eastern and Western regions of the Mediterranean Sea (Figure 2).

Large-sized dust particles are responsible for most of the dry deposition measured in the ocean (Chester et al., 1999; Koçak et al., 2007), with Fe mostly found in the coarse fraction of the mineral aerosols (Duce et al., 1991). In our study, the highest aerosol density obtained from the satellite observations was detected between stations 30 and 32 (range 27.9-28.7 $\mu \mathrm{g} \mathrm{cm}^{-2}$ ) and those results matched with the highest concentrations of Fe, Mo, and V (46.7 $\mathrm{nmol} \mathrm{m}^{-3}, 106.0 \mathrm{pmol} \mathrm{m}^{-3}, 961.2 \mathrm{pmol}$ $\mathrm{m}^{-3}$, respectively) measured in the same area during the second transect of our cruise (Figure 2 and Table 1). The high 

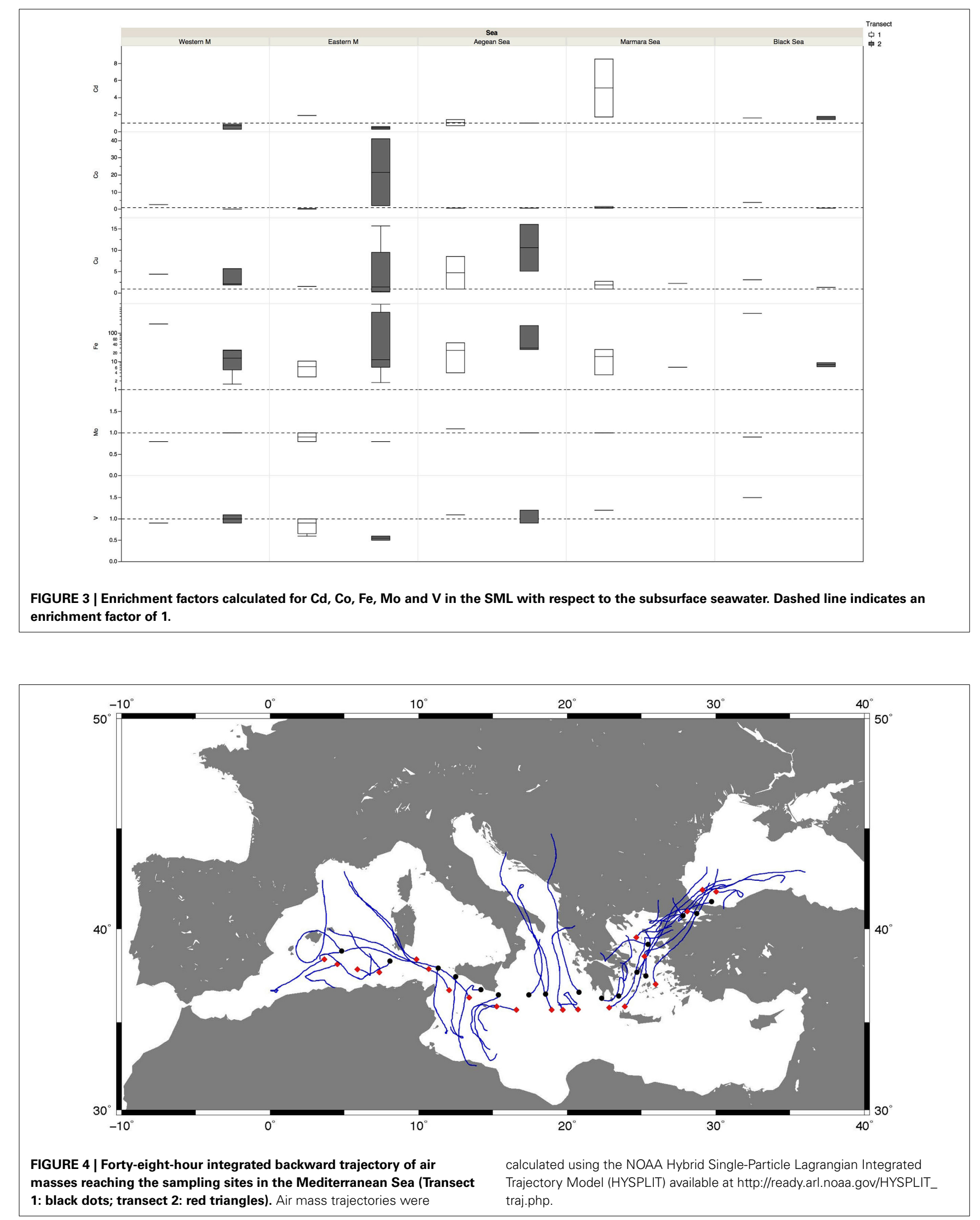
concentrations of $\mathrm{Fe}, \mathrm{V}$, and Mo suggest a mixture of natural and anthropogenic particles as Mo and V have been used as tracers for oil combustion (Addison et al., 1986; De Foy et al., 2012). While $\mathrm{Cd}$ and $\mathrm{Co}$ in our coarse aerosols samples were below our detection limits, $\mathrm{Cu}$ showed the highest concentration in the westernmost stations, also influenced by anthropogenic aerosols from Europe (Jordi et al., 2012) (Figure 4). Cadmium and Co were not detected in our samples suggesting that those two elements must be associated with the fine fraction of the mineral aerosols.

The concentration of Fe in the SML was punctually enhanced during the high aerosol dust event that occurred during the second transect of our cruise (Figure 2). The concentration of Fe in the aerosols increased, on average 10-fold (but up to 30 fold in the eastern sector) in the 7-26 day interval between the two transects (from $2.4 \pm 1.4 \mathrm{nmol} \mathrm{m}^{-3}$ in the first transect, in stations 2-14 to $23.9 \pm 12.0 \mathrm{nmol} \mathrm{m}^{-3}$ during the dust event in the second transect, in stations 21-34). The concentration of Fe in the SML at the same stations experienced a parallel increase, from $274.0 \pm 257.9$ to $985.1 \pm 2547.3 \mathrm{nM}$ between the two transects. However, the high averages calculated during the second transect are influenced by the high concentrations measured in station 29 $(9024 \mathrm{nM})$ and stations 24 and 26 (963 and $685 \mathrm{nM}$, respectively). Despite this Fe increase in the SML, the high aerosol input was only slightly reflected in the TSSW pool (from $6.3 \pm 2.6 \mathrm{nM}$ to $11.3 \pm 8.2 \mathrm{nM}$ ) and not detectable in the DSSW where concentrations remained relatively constant in both transects (from $2.7 \pm$ $1.2 \mathrm{nM}$ to $3.4 \pm 1.6 \mathrm{nM}$ ) (Figure 2). This finding suggests that although most of the aerosol Fe in the Mediterranean is contained within the SML, this Fe pool does not exchange very fast with the DSSW fraction where most of the bioavailable Fe is found. These results are consistent with the uncoupling between dust deposition events and the vertical export flux of particulate metals recently reported for the Western Mediterranean (Heimbürger et al., 2014) and the lack of a link between dust supply and a rapid biological response (Eker-Develi et al., 2006). While Mo and V were also enriched (3-5 times) in aerosols particles during the dust event (stations 21-34), this increase did not coincide with in a similar enrichment in the SML probably as a consequence of the low reactivity of oxyanions in seawater (Figures 2,3 and Table 1).

\section{THE ROLE OF THE SML IN THE METAL BUDGET OF THE MEDITERRANEAN BASIN}

A simple mass balance was used to determine the relative importance of the SML pool to the metal budget of the Mediterranean basin. With a surface area of $2.510^{6} \mathrm{~km}^{2}$, an average concentration of Fe in our survey (excluding the enclosed basins of the Marmara and Black Seas) and a SML thickness of $26 \mu \mathrm{m}$ (see method section), we estimated that SML of the Mediterranean Sea contains about 2.2 tons of Fe. This amount represents between 0.2 and $0.5 \%$ of the TSSW and DSSW pools of Fe over the top meter of the surface sea, respectively (1289 and 412 tons of Fe in the TSSW and DSSW, respectively). Nevertheless, our results also showed that the percentage of the Fe pool contained in the SML could account for up to 3 and $12 \%$ of the TSSW and DSSW pools in the top-meter of the surface layer, respectively, during an episodic dust event (e.g., station 29 in the Eastern Mediterranean during the second transect). The total amount of metals, other than $\mathrm{Fe}$, found in SML was only $<0.15 \%$ of the mass found in the TSSW and DSSW pools. However, our mass balance estimates were carried out for the whole Mediterranean Sea and therefore, the relative contribution of the SML to the total metal pool of other smaller basins within the Mediterranean Sea could be significantly higher. Nevertheless, our analyses suggest that the SML must be considered to better constrain the potential effect of atmospheric inputs of some trace metals (e.g., Fe) on biological processes in the sea.

\section{ASSOCIATION NETWORK ANALYSIS}

An association network(s) analysis based on significant positive correlation analysis was used to visualize relationships among the different metals pools and their influence on bacterial abundance and phytoplankton biomass along our cruise. This analysis was carried out by pooling all the data generated during each transect of the cruise (Figure 5A: Transect 1 and Figure 5B: Transect 2 ). The results of the first cruise analysis, during low aerosol load conditions, showed two distinctive clusters (Figure 5A): a cluster caused by the correlations observed for the oxyanions, Mo and V in the different water column pools (SML, TSSW, and DSSW); and a second cluster formed between the concentrations of $\mathrm{Cd}, \mathrm{Co}, \mathrm{Cu}$, and $\mathrm{Fe}$ measured in the dissolved and total pools (DSSW and TSSW) with the biological parameters (biomass of phytoplankton, as chlorophyll-a, and bacteria abundance in the SML and in the underlying water). This second cluster suggests that the bioavailable pool of trace metals was not in the SML but in the dissolved fraction. Except for $\mathrm{V}$, no relationship among metal concentrations in any of the water compartments (SML, DSSW, and TSSW) and their concentrations in aerosols was observed. The correlation of $\mathrm{V}$ with the total amount of dust particles suggest that under low dust conditions, the chemical composition of the aerosols collected along the Mediterranean was influenced by anthropogenic sources (De Foy et al., 2012), although this correlation was biased by the high levels of this element measured at stations 9 and 11 in the Eastern Mediterranean and Aegean Sea (Figure 2). This analysis also showed that the distribution of metals in the SML during the first transect of our cruise was independent of dust concentrations as well as the TSSW and DSSW pools. The second cruise results also showed two clusters (Figure 5B). However, during this cruise the effect of the dust deposition event was more pronounced, as indicated by the correlation between the total amount of dust particles (reported as MODIS_Aero) with the actual Fe and Mo concentrations measured in the collected dust. As observed in the first transect of our cruise, biological parameters were independent of the SML metal composition.

Our results suggest that the biological response, as well as the concentrations of total and dissolved pools of active elements in the subsurface layer, are not immediately influenced by the metals present in the SML. However, this metal compartment might act as trap for aerosols particles and the retention capacity of the SML as well as the transfer rate to other reservoirs is poorly understood and needs to be evaluated in future studies. 


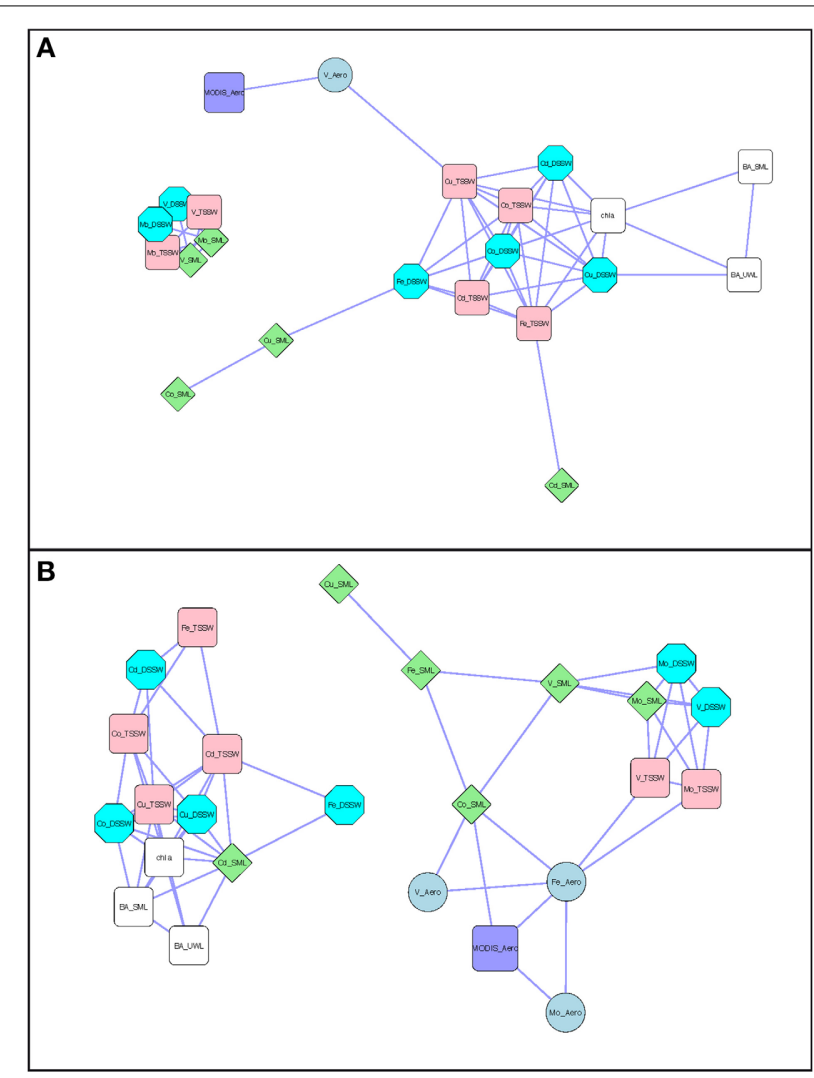

FIGURE 5 | Network analysis results obtained for transect 1 (A) and transect 2 (B). Elements in the surface microlayer (SML): Cd_SML, Co_SML, Cu_SML, Fe_SML, Mo_SML and V_SML; elements in the unfiltered fraction of the subsurface water (TSSW): Cd_TSSW, Co_TSSW, Cu_TSSW, Fe_TSSW, Mo_TSSW and V_TSSW; Elements in the dissolved fraction of the subsurface water (DSSW); Cd_DSSW, Co_DSSW, Cu_DSSW, Fe_DSSW, Mo_DSSW and V_DSSW; Elements in aerosols particles (Aero): Fe_Aero, Mo_Aero and V_Aero; Density of particles in the atmosphere from satellite observations (MODIS_Aero); chlorophyll-a concentrations (chla); and bacterial abundance in the SML (BA_SML) and in the underlying water column (BA_UWL). Nodes (SML: green diamonds; TSSW, red squares; DSSW, cyan octagons; Aero: blue circles; MODIS_Aero, purple square; chla and $\mathrm{Ba} \_\mathrm{SML}$ and $\mathrm{Ba}$ _UWL: white squares) correspond to the measured concentrations or abundances of the variables and edges represent a significant $(p<0.05)$ positive correlation between the two variables linked.

\section{CONCLUSION}

The Mediterranean Sea SML is enriched in reactive metals, such as $\mathrm{Cd}, \mathrm{Co}, \mathrm{Cu}, \mathrm{Fe}$ over the metal fractions measured in the subsurface water. We estimated that the SML of the Mediterranean Sea contains a significant amount of Fe. However, the effect of bioactive trace metals found in the SML on the biological activity of the Mediterranean Sea was not immediately observed in our network analysis. These findings are particularly important for understanding the biogeochemistry of the Mediterranean Sea where atmospheric inputs are the main source of metals to the open waters of this important marine region (Migon, 2005).

\section{ACKNOWLEDGMENTS}

This work was supported by the project THRESHOLDS (CTM2005-24238-E) funded by the EU-FP6. We thank the crew of BIO García del Cid and the rest of the THRESHOLDS participants for cooperative work at sea. We also thank A. Massanet for technical assistance and J. F. González (Serveis Cientificotècnics, UIB) for technical support with the ICP-MS and ICP-AES.

\section{REFERENCES}

Addison, R. F., Mckague, A. B., Larsson, Å., Mcleay, D. J., Ney, P. E., Parker, G. A., et al. (1986). Anthropogenic Compounds. Berlin, Heidelberg: Springer. Available at: http://link.springer.com/10.1007/978-3-540-39468-6. (Accessed May 21, 2014).

Agogué, H., Casamayor, E. O., Joux, F., Obernosterer, I., Dupuy, C., Lantoine, F., et al. (2004). Comparison of samplers for the biological characterization of the sea surface microlayer. Limnol. Oceanogr. Methods 2, 213-225. doi: 10.4319/lom.2004.2.213

Aparicio-González, A., Duarte, C. M., and Tovar-Sánchez, A. (2012). Trace metals in deep ocean waters: a review. J. Mar. Syst. 100-101, 26-33. doi: 10.1016/j.jmarsys.2012.03.008

Bonnet, S., and Guieu, C. (2006). Atmospheric forcing on the annual iron cycle in the western Mediterranean Sea: a 1-year survey. J. Geophys. Res. 111, C09010. doi: 10.1029/2005JC003213

Bruland, K. W., Franks, R. P., Knauer, G. A., and Martin, J. H. (1979). Sampling and analytical methods for the determination of copper, cadmium, zinc, and nickel at the nanogram per liter level in sea water. Anal. Chim. Acta 105, 233-245. doi: 10.1016/S0003-2670(01)83754-5

Bruland, K. W., and Lohan, M. C. (2006). Controls of trace metals in seawater. Oceans Mar. Geochem. Elsevier, 6, 23-47. doi: 10.1016/B0-08-043751-6/ 06105-3

Buck, C. S., Landing, W. M., Resing, J. A., and Measures, C. I. (2010). The solubility and deposition of aerosol Fe and other trace elements in the North Atlantic Ocean: observations from the A16N CLIVAR/CO2 repeat hydrography section. Mar. Chem. 120, 57-70. doi: 10.1016/j.marchem.2008.08.003

Chester, R., Nimmo, M., and Preston, M. (1999). The trace metal chemistry of atmospheric dry deposition samples collected at Cap Ferrat: a coastal site in the Western Mediterranean. Mar. Chem. 68, 15-30. doi: 10.1016/S03044203(99)00062-6

Chu, P. C., Ivanov, L. M., and Margolina, T. M. (2005). Seasonal variability of the Black Sea chlorophyll-a concentration. J. Mar. Syst. 56, 243-261. doi: 10.1016/j.jmarsys.2005.01.001

Cincinelli, A., Stortini, A. M., Perugini, M., Checchini, L., and Lepri, L. (2001). Organic pollutants in sea-surface microlayer and aerosol in the coastal environment of Leghorn-(Tyrrhenian Sea). Mar. Chem. 76, 77-98. doi: 10.1016/S03044203(01)00049-4

De Foy, B., Smyth, A. M., Thompson, S. L., Gross, D. S., Olson, M. R., Sager, N., et al. (2012). Sources of nickel, vanadium and black carbon in aerosols in Milwaukee. Atmos. Environ. 59, 294-301. doi: 10.1016/j.atmosenv.2012.06.002

Duce, R. A., Liss, P. S., Merrill, J. T., Atlas, E. L., Buat-Menard, P., Hicks, B. B., et al. (1991). The atmospheric input of trace species to the World Ocean. Glob. Biogeochem. Cycles 5, 193-259. doi: 10.1029/91GB01778

Eker-Develi, E., Kideys, A. E., and Tugrul, S. (2006). Role of Saharan dust on phytoplankton dynamics in the northeastern Mediterranean. Mar. Ecol. Prog. Ser. 314, 61-75. doi: 10.3354/meps314061

Emerson, S. R., and Huested, S. S. (1991). Ocean anoxia and the concentrations of molybdenum and vanadium in seawater. Mar. Chem. 34, 177-196. doi: 10.1016/0304-4203(91)90002-E

Heimbürger, L.-E., Migon, C., Losno, R., Miquel, J.-C., Thibodeau, B., Stabholz, M., et al. (2014). Vertical export flux of metals in the Mediterranean Sea. Deep Sea Res. Part Oceanogr. Res. Pap. 87, 14-23. doi: 10.1016/j.dsr.2014. 02.001

Jordi, A., Basterretxea, G., Tovar-Sánchez, A., Alastuey, A., and Querol, X. (2012). Copper aerosols inhibit phytoplankton growth in the Mediterranean Sea. Proc. Natl. Acad. Sci. U.S.A. 109, 21246-21249. doi: 10.1073/pnas. 1207567110

Koçak, M., Kubilay, N., Herut, B., and Nimmo, M. (2007). Trace metal solid state speciation in aerosols of the Northern Levantine Basin, East Mediterranean. J. Atmospheric Chem. 56, 239-257. doi: 10.1007/s10874-006-9053-7 
Lewis, B. L., and Landing, W. M. (1992). The investigation of dissolved and suspended-particulate trace metal fractionation in the Black Sea. Mar. Chem. 40, 105-141. doi: 10.1016/0304-4203(92)90050-K

Liss, P. S., and Duce, R. A. (1997). The Sea Surface and Global Change [...] [...]. Cambridge: Cambridge Univ. Press.

Marie, D., Partensky, F., Jacquet, S., and Vaulot, D. (1997). Enumeration and cell cycle analysis of natural populations of marine picoplankton by flow cytometry using the nucleic acid stain SYBR green I. Appl. Environ. Microbiol. 63, 186-193.

Migon, C. (2005). "Trace metals in the Mediterranean Sea," in The Mediterranean Sea Handbook of Environmental Chemistry, ed A. Saliot (Berlin; Heidelberg: Springer), 151-176. Available online at: http://link.springer.com/chapter/10. 1007/b107146. (Accessed November 26, 2013).

Millero, F. J. (2006). Chemical Oceanography. Boca Raton, FL: CRC/Taylor and Francis.

OGUZ, T. (2005). Anthropogenic Forcing. Oceanography 18, 112.

Okuş, E., Balkıs, N., Müftüoğlu, E., and Aksu, A. (2007). Metal (Pb, Cd and $\mathrm{Hg}$ ) inputs via the rivers to the Southern Marmara Sea Shelf, Turkey. J. Black Sea/Medit. Environ. 13. (Accessed April 1, 2014). Available online at: http:// www.blackmeditjournal.org/index.asp

Parsons, T. R., Maita, Y., and Lalli, C. M. (1984). A Manual of Chemical and Biological Methods for Seawater Analysis. Oxford: Pergamon Press.

Pekney, N. J., and Davidson, C. I. (2005). Determination of trace elements in ambient aerosol samples. Anal. Chim. Acta 540, 269-277. doi: 10.1016/j.aca.2005.03.065

Shannon, P., Markiel, A., Ozier, O., Baliga, N. S., Wang, J. T., Ramage, D., et al. (2003). Cytoscape: a software environment for integrated models of biomolecular interaction networks. Genome Res. 13, 2498-2504. doi: 10.1101/gr.1239303

Stortini, A. M., Cincinelli, A., Degli Innocenti, N., Tovar-Sánchez, A., and Knulst, J. (2012). "1.12 - Surface Microlayer," in Comprehensive Sampling and Sample Preparation, ed J. Pawliszyn (Oxford: Academic Press), 223-246. Available online at: http://www.sciencedirect.com/science/article/pii/ B9780123813732000181. (Accessed October 1, 2012).

Ternon, E., Guieu, C., Loÿe-Pilot, M.-D., Leblond, N., Bosc, E., Gasser, B., et al. (2009). The impact of Saharan dust on the particulate export in the water column of the North Western Mediterranean Sea. Biogeosci. Discuss 6, 10737-10773. doi: 10.5194/bgd-6-10737-2009

Tovar-Sánchez, A. (2012). "1.17 - sampling approaches for trace element determination in seawater," in Comprehensive Sampling and Sample Preparation, ed J. Pawliszyn (Oxford: Academic Press), 317-334. Available online at: http:// www.sciencedirect.com/science/article/pii/B978012381373200017X. (Accessed October 1, 2012).
Vega, M., and van den Berg, C. M. G. (1997). Determination of cobalt in seawater by catalytic adsorptive cathodic stripping voltammetry. Anal. Chem. 69, 874-881. doi: $10.1021 /$ ac960214s

Wurl, O. (2009). Practical Guidelines for the Analysis of Seawater, 1st Edn. Oxford: CRC Press.

Wurl, O., and Holmes, M. (2008). The gelatinous nature of the sea-surface microlayer. Mar. Chem. 110, 89-97. doi: 10.1016/j.marchem.2008.02.009

Wurl, O., Karuppiah, S., and Obbard, J. P. (2006). The role of the seasurface microlayer in the air-sea gas exchange of organochlorine compounds. Sci. Total Environ. 369, 333-343. doi: 10.1016/j.scitotenv.2006. 05.007

Wurl, O., and Obbard, J. P. (2004). A review of pollutants in the sea-surface microlayer (SML): a unique habitat for marine organisms. Mar. Pollut. Bull. 48, 1016-1030. doi: 10.1016/j.marpolbul.2004. 03.016

Wurl, O., Wurl, E., Miller, L., Johnson, K., and Vagle, S. (2011). Formation and global distribution of sea-surface microlayers. Biogeosciences 8, 121-135. doi: 10.5194/bg-8-121-2011

Yoon, Y.-Y., Martin, J.-M., and Cotté, M. H. (1999). Dissolved trace metals in the Western Mediterranean Sea: total concentration and fraction isolated by C18 Sep-Pak technique. Mar. Chem. 66, 129-148. doi: 10.1016/S03044203(99)00033-X

Conflict of Interest Statement: The authors declare that the research was conducted in the absence of any commercial or financial relationships that could be construed as a potential conflict of interest.

Received: 09 October 2014; accepted: 02 December 2014; published online: 18 December 2014.

Citation: Tovar-Sánchez A, Arrieta JM, Duarte CM and Sañudo-Wilhelmy SA (2014) Spatial gradients in trace metal concentrations in the surface microlayer of the Mediterranean Sea. Front. Mar. Sci. 1:79. doi: 10.3389/fmars.2014.00079

This article was submitted to Marine Biogeochemistry, a section of the journal Frontiers in Marine Science.

Copyright (C) 2014 Tovar-Sánchez, Arrieta, Duarte and Sañudo-Wilhelmy. This is an open-access article distributed under the terms of the Creative Commons Attribution License (CC BY). The use, distribution or reproduction in other forums is permitted, provided the original author(s) or licensor are credited and that the original publication in this journal is cited, in accordance with accepted academic practice. No use, distribution or reproduction is permitted which does not comply with these terms. 